\title{
Verbal Rating Scale 5-Point
}

National Cancer Institute

\section{Source}

National Cancer Institute. Verbal Rating Scale 5-Point. NCI Thesaurus. Code C158272.

A type of verbal rating scale composed of 5 items. 